\title{
Impact of severe malnutrition on clinical signs of pneumonia in under-5- year-old children: A hospital based study
}

\author{
*Bodhrun Naher ${ }^{1}$, Sheikh Shamsunnahar Shamme², Nazma Begum ${ }^{3}$ \\ Sri Lanka Journal of Child Health, 2022; 51(1): 99-105 \\ DOI: http://dx.doi.org/10.4038/sljch.v51i1.10003
}

\begin{abstract}
Background: Pneumonia is a major cause of under-5year mortality in developing countries including Bangladesh. Malnourished children are more vulnerable to develop pneumonia and pneumonia associated case morbidity and mortality.
\end{abstract}

Objectives: To evaluate the impact of severe malnutrition on clinical signs of pneumonia in children and the outcome.

Method: A total of 150 eligible children aged 2 months to 5 years was enrolled in this descriptive case control study. Of them 75 were included as cases in Group A with severe malnutrition with pneumonia and in Group B, 75 well-nourished children having pneumonia were included as controls. Age range of Cases and Controls was 2 months to 5 years.

Results: The mean weight-for-height/length $\mathrm{Z}$ score of cases was $-3.25 \pm 1.68$ and in controls was -0.35 \pm 0.89 . The mean height-for-age $\mathrm{Z}$ score of cases was $-1.93 \pm 1.52$ and in controls was $-0.82 \pm 0.72$. In group A, 50 (67\%) children had bipedal symmetrical oedema. In Group A, $50(67 \%)$ cases had no fast breathing in comparison to three (04\%) in Group B. Fast breathing was twenty times less likely to be present in pneumonia with severe malnutrition $(\mathrm{OR}=20.18)$. This study also showed that chest indrawing was present only in $23(30 \%)$ cases in comparison to 59 (79\%) controls . Chest indrawing was ten times less

\footnotetext{
${ }^{1}$ Junior Consultant, Department of Paediatrics, Mugda Medical College and Hospital, Dhaka, Bangladesh, ${ }^{2} J$ unior Consultant, Department of Paediatrics, District Hospital, Kishoreganj, Bangladesh, ${ }^{3}$ Professor, Department of Paediatrics, Mugda Medical College and Hospital, Dhaka, Bangladesh

*Correspondence: bodhrunnaher@gmail.com

(iD)

https//orcid.org/ 0000-0001-9899-8582
}

(Received on 18 May 2021: Accepted after revision on 18 June 2021)

The authors declare that there are no conflicts of interest

Personal funding was used for the project.

Open Access Article published under the Creative

Commons Attribution CC-BY (c) (i) License likely to be present in pneumonia with severe malnutrition $(\mathrm{OR}=10.06)$.

Conclusions: It can be concluded from this study that the definitions of fast breathing and chest indrawing recommended by Integrated Management of Childhood Illness (IMCI) are not sufficiently reliable predictors of pneumonia in severely malnourished children. The study supports the recommendation of IMCI for referring severely malnourished children with an acute illness with cough and/or difficult breathing to hospital with or without fast breathing or chest indrawing.

(Key words: Clinical signs, Pneumonia, Under-5 children, Severe malnutrition, Chest indrawing, Fast breathing)

\section{Introduction}

Pneumonia remains a major killer of under-fiveyear-old children and accounts for nearly one fifth of childhood deaths worldwide ${ }^{1}$. Pneumonia causes more deaths in children than any other illness ${ }^{2}$. Few caregivers in developing countries recognise that fast and difficult breathing are the two key symptoms of pneumonia indicating the need for immediate treatment ${ }^{3}$. Early recognition and prompt treatment of pneumonia can save lives ${ }^{4}$. Acute Lower Respiratory Infections (ALRI) is the most important cause of death in Bangladeshi children ${ }^{5}$. About $25 \%$ of the deaths in Bangladeshi children are associated with $\mathrm{ALRI}^{6}$. The median case fatality rate from severe malnutrition has remained unchanged during the last 50 years at around 20\%-30\%

Pneumonia is one of the most serious complications of severe acute malnutrition ${ }^{8}$. A child with severe malnutrition has an increased risk of death from pneumonia without showing the typical signs of pneumonia ${ }^{9}$. Cough, one of the most noticeable defense mechanism, is dependent on respiratory muscle strength. Wasted individuals have decreased respiratory muscle strength and reduced diaphragmatic muscle mass which precipitates bronchopneumonia ${ }^{10}$. It is suggested that severely malnourished children with cough or difficulty in breathing receive antibiotics as they might have pneumonia without any obvious sign like fast breathing ${ }^{11}$. Severely malnourished children have three times more chance of death from ALRI than 
children with normal or mild malnutrition associated with $\mathrm{ALRI}^{12}$. A severely malnourished child may have an impaired or absent response to hypoxia and a weak or absent cough reflex for which careful management is needed because case fatality rates are higher in such children ${ }^{13}$.

\section{Objectives}

To evaluate the impact of severe malnutrition on clinical signs of pneumonia in children aged 2 months to 5 years and to compare the clinical signs of pneumonia, classified according to Integrated Management of Childhood Illness (IMCI) protocol, between severely malnourished (weight for height/length less than -3Z) and those of wellnourished children (weight for height/length more than $-2 Z$ ).

\section{Method}

This hospital based descriptive case control study was carried out in the Department of Paediatrics, Mugda Medical College and Hospital, Dhaka, Bangladesh, from January 2017 to December 2018.

Inclusion criteria: A total of two hundred and fiftythree hospitalized children, aged 2 months to 5 years, who presented with cough and / or difficult breathing were enrolled in this study.

Exclusion criteria: Children having malnutrition due to non-nutritional causes and lung diseases other than radiological evidence of pneumonia were excluded from the study. Protein energy malnutrition (PEM) with primary diseases like septicaemia, congenital heart disease, acute watery diarrhea or meningitis, which can influence the respiratory rate and respiratory pattern, were also not included as cases.

Following exclusion, a total of 150 children were divided into 75 group A children, having severe malnutrition with pneumonia, as Cases and 75 wellnourished group B children having pneumonia as Controls.

Severe malnutrition in this age group was diagnosed when children of both sexes had bilateral symmetrical pedal oedema and /or weight-forlength/height $<70 \%$ of National Centre for Health Statistics (NCHS) mean or weight-for-length/height $\mathrm{Z}$ score less than -3 .

In the Control group, normal nourishment was identified when children (age and sex matched with cases) had weight-for-length/ height $>80 \%$ mean of NCHS mean or weight-for-length/ height Z score more than -2 with absence of bilateral symmetrical pedal oedema.
A pre-tested questionnaire was designed and standard clinical examinations were performed. Nutritional status of the study population was determined immediately after admission.

Weight was measured by standard weighing scale with minimum clothes or naked without shoes.

Length / height was measured with locally constructed wooden board (infantometer) or wooden frame (stadiometer).

Fast breathing / tachypnoea was determined according to criteria recommended by the World Health Organisation (WHO); in children between 2 to 12 months old $\geq 50$ / minute and in children older than 12 months up to 5 years $\geq 40$ /minute.

Lower chest indrawing (LCI), defined as an inward movement of the bony structures of the lower chest wall with inspiration, was observed and recorded.

A thorough clinical examination was done and recorded in the case recording form. Complete blood count, relevant laboratory investigations and chest $\mathrm{x}$-ray were done in all cases and controls within 24 hours of admission. X-rays were interpreted by the radiologist for more reliable diagnosis. Radiologically pneumonia was diagnosed as patchy opacities or consolidation. The $\mathrm{x}$-ray result was taken as gold standard for the diagnosis of pneumonia.

Ethical issues: Approval for the study was obtained from the Institutional Review Board (IRB) of Mugda Medical College and Hospital, Mugda, Dhaka, Bangladesh (No. MuMCH/2017/212). Informed written consent was obtained from the parents of all children involved in the study.

Statistical analysis: After completion of data collection statistical analysis was done with the help of Statistical Package of Social Service (SPSS) version 25.0 and subsequently appropriate statistical tests were done. To find out the strength of association, odds ratio was estimated and the $95 \%$ confidence interval was taken as the precision of the result.

\section{Results}

A total of 150 hospitalized children who fulfilled the inclusion criteria were included in the study. The baseline characteristics of the study population are shown in Table 1. Table 2 shows the mean age groups of the studied children. Figure 1 shows the frequency of pneumonia according to age in cases and controls. Table 3 shows the mean values and standard deviation of anthropometry of cases and controls 
Table-1: Baseline characteristics of study population $(n=150)$

\begin{tabular}{|c|c|c|}
\hline Characteristic & $\begin{array}{c}\text { Group A - Cases }(n=75) \\
n(\%)\end{array}$ & $\begin{array}{c}\text { Group B - Controls }(n=75) \\
n(\%)\end{array}$ \\
\hline $\begin{array}{l}\text { Age } \\
2 \text { months up to } 12 \text { months } \\
1 \text { year up to } 5 \text { years }\end{array}$ & $\begin{array}{l}52(69) \\
23(31)\end{array}$ & $\begin{array}{l}56(75) \\
19(25)\end{array}$ \\
\hline $\begin{array}{l}\text { Gender } \\
\text { Male } \\
\text { Female }\end{array}$ & $\begin{array}{l}40(53) \\
35(47)\end{array}$ & $\begin{array}{l}51(68) \\
24(32) \\
\end{array}$ \\
\hline $\begin{array}{l}\text { Socio-economic status (monthly income) } \\
\text { Poor }(<5000 \text { taka) } \\
\text { Lower middle }(5000-10,000 \text { taka }) \\
\text { Middle }(10,001-15,000 \text { taka }) \\
\text { Affluent }(>15,000 \text { taka) }\end{array}$ & $\begin{array}{l}68(90) \\
05(07) \\
02(03) \\
00(00)\end{array}$ & $\begin{array}{l}16(21) \\
45(60) \\
12(16) \\
02(03)\end{array}$ \\
\hline $\begin{array}{l}\text { Residence } \\
\text { Urban } \\
\text { Slum } \\
\text { Rural }\end{array}$ & $\begin{array}{l}36(48) \\
18(24) \\
21(28)\end{array}$ & $\begin{array}{l}53(71) \\
06(08) \\
16(21)\end{array}$ \\
\hline $\begin{array}{l}\text { Immunization } \\
\text { Completely Immunized } \\
\text { Partially Immunized } \\
\text { Continuing Immunization } \\
\text { Not Immunized }\end{array}$ & $\begin{array}{l}26(35) \\
21(28) \\
23(30) \\
05(07)\end{array}$ & $\begin{array}{l}22(29) \\
00(00) \\
51(68) \\
02(03)\end{array}$ \\
\hline
\end{tabular}

Table 2: Mean age groups of the studied children $(n=150)$

\begin{tabular}{|c|c|c|c|}
\hline \multicolumn{2}{|c|}{ Group A - Cases $(\boldsymbol{n}=\mathbf{7 5})$} & \multicolumn{2}{c|}{ Group B - Controls $(\boldsymbol{n}=\mathbf{7 5})$} \\
\hline $\mathbf{2}$ to 12 months $(\boldsymbol{n}=\mathbf{5 2})$ & $\mathbf{1}$ to 5 years $(\boldsymbol{n}=\mathbf{2 3})$ & $\mathbf{2}$ to 12 months $(\boldsymbol{n}=\mathbf{5 6})$ & $\mathbf{1}$ to 5 years $(\boldsymbol{n}=\mathbf{1 9})$ \\
\hline Mean $\pm \mathrm{SD}$ & Mean $\pm \mathrm{SD}$ & Mean $\pm \mathrm{SD}$ & Mean \pm SD \\
\hline $8.28 \pm 3.08)$ & $23.30 \pm 12.95$ & $5.55 \pm 2.81$ & $26.31 \pm 9.89$ \\
\hline
\end{tabular}

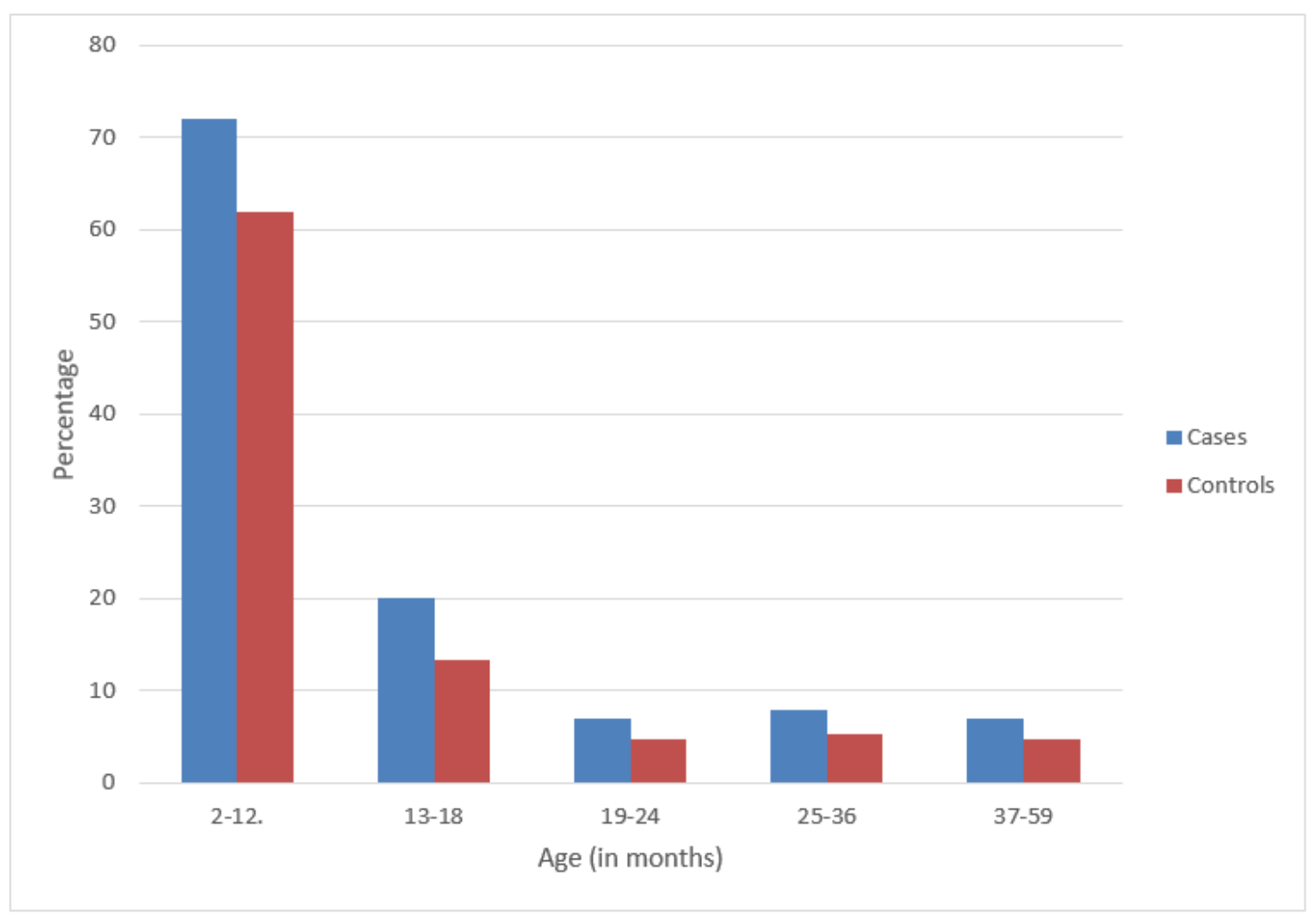

Figure 1: Frequency of pneumonia according to age in cases and controls 
Table 3: Mean values and standard deviation of anthropometry of cases and controls $(n=150)$

\begin{tabular}{|l|c|c|c|c|}
\hline \multicolumn{1}{|c|}{ Studied children } & $\begin{array}{c}\text { Wt for Ht/length\% } \\
\text { NCHS mean }\end{array}$ & $\begin{array}{c}\text { Wt for Ht/length } \\
\text { Z score }\end{array}$ & $\begin{array}{c}\text { Ht for Age\% } \\
\text { NCHS mean }\end{array}$ & $\begin{array}{c}\text { Ht for Age } \\
\text { Z score }\end{array}$ \\
\hline $\begin{array}{l}\text { Group A ( }=75) \\
\text { Mean } \pm \text { SD }\end{array}$ & $80.79 \pm 14.04$ & $-3.25 \pm 1.68$ & $86.52 \pm 6.40$ & $-1.93 \pm 1.52$ \\
\hline $\begin{array}{l}\text { Group B (n=75) } \\
\text { Mean } \pm \text { SD }\end{array}$ & $96.58 \pm 8.74$ & $-0.35 \pm 0.89$ & $95.93 \pm 2.42$ & $-0.82 \pm 0.72$ \\
\hline
\end{tabular}

Wt: Weight, Ht: Height, SD: standard deviation

Table 4 shows the association of oedema in severe malnutrition with pneumonia in the studied children, Oedema was more common in the $50(67 \%)$ children with severe protein energy malnutrition (PEM) with pneumonia compared with the $25(33 \%)$ children with no oedema and this finding was statistically significant $(\mathrm{p}<0.01)$.

Table 4: Association of oedema in severe malnutrition with pneumonia in studied children ( $n=75)$

\begin{tabular}{|l|c|c|c|c|}
\hline \multicolumn{1}{|c|}{ Oedema status } & $\begin{array}{c}\text { Group A } \\
\text { n (\%) }\end{array}$ & Odds Ratio & $\begin{array}{c}\mathbf{9 5 \%} \text { confidence } \\
\text { interval }\end{array}$ & p-value \\
\hline Oedema & $50(67)$ & 0.25 & $0.178-0.351$ & $<0.01$ \\
\hline No oedema & $25(33)$ & & & \\
\hline
\end{tabular}

Table 5 shows the association of fast breathing with pneumonia in cases and controls. Fast breathing was absent in $67 \%$ of cases in comparison to $4 \%$ of controls who were later diagnosed as atypical pneumonia and the finding was statistically significant $(p<0.001)$. Fast breathing was twenty times less likely to be present in pneumonia with severe malnutrition $(\mathrm{OR}=20.18)$.

Table 5: Association of fast breathing with pneumonia in cases and controls $(n=150)$

\begin{tabular}{|l|c|c|c|c|c|}
\hline Fast breathing & $\begin{array}{c}\text { Group A (n=75) } \\
\mathbf{n}(\%)\end{array}$ & $\begin{array}{c}\text { Group B (n=75) } \\
\mathbf{n}(\mathbf{\%})\end{array}$ & Odds Ratio & $\begin{array}{c}\mathbf{9 5 \%} \text { confidence } \\
\text { interval }\end{array}$ & p-value \\
\hline Present & $25(33)$ & $72(96)$ & 20.18 & $7.74-54.46$ & $<0.001$ \\
\hline Absent & $50(67)$ & $03(04)$ & & & \\
\hline
\end{tabular}

Table 6 shows the association of chest indrawing with pneumonia in cases and controls. Chest indrawing was present in $31 \%$ of severely malnourished children suffering from pneumonia in comparison to $79 \%$ of better-nourished children with pneumonia.
This was also found to be statistically significant $(\mathrm{p}<0.001)$. Chest indrawing was ten times less likely to be present in pneumonia with severe malnutrition $(\mathrm{OR}=10.06)$.

Table 6: Association of chest indrawing with pneumonia in cases and controls $(n=150)$

\begin{tabular}{|l|c|c|c|c|c|}
\hline $\begin{array}{c}\text { Chest } \\
\text { indrawing }\end{array}$ & $\begin{array}{c}\text { Group A (n=75) } \\
\text { n (\%) }\end{array}$ & $\begin{array}{c}\text { Group B (n=75) } \\
\mathbf{n}(\%)\end{array}$ & Odds Ratio & $\begin{array}{c}\text { 95\% confidence } \\
\text { interval }\end{array}$ & p-value \\
\hline Present & $23(31)$ & $59(79)$ & 10.06 & $4.47-22.99$ & $<0.001$ \\
\hline Absent & $52(69)$ & $16(21)$ & & & \\
\hline
\end{tabular}

\section{Discussion}

Malnutrition is a serious health problem for children in developing countries, afflicting and killing millions of children each year ${ }^{14}$. It is a major known health problem in Bangladeshi children ${ }^{11}$. Even in the year 2005 , about $35 \%$ of the global population had been suffering from malnutrition of various degrees ${ }^{15}$. One hundred Bangladeshi children aged under 5 years, hospitalized for therapy of severe malnutrition were assessed for the presence of infection; $90 \%$ had evidence of infection at the time of admission and $75 \%$ had pneumonia ${ }^{16}$. Of childhood deaths in Bangladesh $66 \%$ are currently attributable to malnutrition even though the immediate cause of death may have been pneumonia or diarrhoea ${ }^{17}$.
To see the impact of severe malnutrition on clinical signs of pneumonia in children, 75 malnourished children (Group A) and 75 well-nourished children (Group B), aged 2 months to 5 years, were studied and compared. The mean age of the studied children was $8.28 \pm 3.08$ months in cases and $5.55 \pm 2.81$ months in controls. Amin MR et ald showed that $77 \%$ of malnourished children were below two years of age. The mean weight for height/length Z-score cases was $-3.25 \pm 1.68$ and that of in controls was $-0.35 \pm 0.89$. The mean height for age Z-score of cases was -1.93 \pm 1.52 and that in controls was $-0.82 \pm 0.72$. In group A, out of 75 cases $50(67 \%)$ had bipedal symmetrical oedema (Table 4$)$. 
Present study revealed that pneumonia was more prevalent in oedematous malnourished children in comparison to non-oedematous malnourished children $(p<0.01)$. Barkowitz $\mathrm{FE}^{19}$ stated that pneumonia is commonly present in severely oedematous malnourished children presenting to health care facilities, occurring in 26 to $49 \%$ of cases. The exact pathophysiology is not known, but it is assumed that Kwashiorkor is a state of adaptation failure. Thus, oedematous malnourished children are more prone to infection than non-oedematous children.

In our study $67 \%$ of cases had no fast breathing in comparison to $4 \%$ in control group. This finding is statistically significant $(\mathrm{OR}=20.18,95 \% \mathrm{CI}=7.74$ 54.46, $\mathrm{p}<0.001$ ) indicating that fast breathing was twenty times less likely to be present in pneumonia with severe malnutrition. In 2003, Antonio Pio, in a WHO bulletin ${ }^{20}$ stated that malnourished children may not have the strength to increase the respiratory rate adequately if their lungs are affected by pneumonia. The lower temperature in malnourished children with pneumonia may also contribute to their lower respiratory rate. For a given sensitivity and specificity they produce about 5 breaths per minute fewer than well-nourished children.

Cough, one of the most noticeable defense mechanisms, is dependent on the respiratory muscle strength. The muscle mass of diaphragm was $43 \%$ lower than normal in underweight patients whose body weight was less than $85 \%$ of ideal. The reduced muscle mass of the diaphragm has been attributed to impaired coughing reflexes ${ }^{14}$. In severely malnourished children with pneumonia, fast breathing and chest indrawing may not be as evident as in other children. Malnutrition can adversely affect lung function and the adverse effects include: decreased ventilatory drive, decreased respiratory muscle function, alterations of lung parenchyma and depressed lung defense mechanisms. A severely malnourished child may have an impaired or absent response to hypoxia and a weak or absent cough reflex. Bhawya Banga ${ }^{21}$ stated that in severely malnourished children with pneumonia, fast breathing and chest indrawing maynot be as evident as in other children. Falade AG, et $a 1^{22}$ in their study stated that with symptoms of ARI, malnourished children do breathe at a slower rate than well-nourished children.

Our study also showed that chest indrawing was present only in $23(30 \%)$ severely malnourished children suffering from pneumonia in comparison to 59 (79\%) well-nourished children with pneumonia. This was also statistically significant $(\mathrm{OR}=10.06,95 \% \mathrm{CI}=4.47$ $22.99, \mathrm{p}<0.001)$ indicating that chest indrawing in pneumonia with severe malnutrition is ten times less likely to be present. It is the reduced muscle mass of the diaphragm that is responsible for impaired coughing reflex and absent/less lower chest indrawing ${ }^{13}$. Arora and Rochester ${ }^{23}$ in their study concluded that with severe loss of body weight, diaphragm mass is reduced to the same extent of total body mass which may be responsible for absent chest indrawing in pneumonia with severe malnutrition in children.

These findings indicated that the definitions of fast breathing and chest indrawing recommended by IMCI are not sufficiently reliable predictors of pneumonia in severely malnourished children and support the recommendation to refer severely malnourished children with an acute illness with cough and/or difficult breathing to hospital for empirical antibiotic therapy ${ }^{24}$. In 1998, Wafula EM et $a \ell^{25}$ stated that the available clinical parameters, singly or in combination, are poor diagnostic tools for pneumonia in children with severe malnutrition. It is advisable to treat children with severe malnutrition having cough/ difficult breathing as if they had pneumonia, even in the absence of suggestive clinical signs ${ }^{26}$.

It is asserted that chest indrawing and fast breathing in pneumonia recommended by IMCI are not sufficiently reliable predictors of pneumonia in severely malnourished children and the following recommendation are made:

- Children with severe malnutrition who present with cough and/or difficult breathing should be confirmed as pneumonia by doing a chest radiograph.

- Presence of oedema in severe malnutrition is an important risk factor risk for developing pneumonia.

However, further broad based and multi-centred studies are required in order to validate the findings of the present study.

\section{Conclusions}

It can be concluded from this study that the definitions of fast breathing and chest indrawing recommended by IMCI are not sufficiently reliable predictors of pneumonia in severely malnourished children. The study supports the recommendation of IMCI for referring severely malnourished children with an acute illness with cough and/or difficult breathing to hospital with or without fast breathing or chest indrawing.

\section{References}

1. WHO/ UNICEF Joint statement on management of pneumonia in community settings. Available from: http://www.WHO/FCH/CAH/04.06

(Accessed on 12 May 2004) 
2. Pneumonia: the leading killer of children. Lancet 2006; 368: 1048-50. https://doi.org/10.1016/S01406736(06)693 34-3

3. Black RE, Morris SS, Bryce J. Child survival. Where and why are 10 million children dying every year? Lancet 2003; 361: 2226-34.

https://doi.org/10.1016/S01406736(03)137 79-8

4. WHO/Acute respiratory infections in children. Available from:

http://www.who.int/fch/depts/cah/resp infections/en/ (Accessed on 5/23/2007)

5. Baqui AH, Sabir AA, Begum N, Arifeen SE, Mitra SN, Black RE. Causes of childhood deaths in Bangladesh: an update. Acta Pediatrica 2001; 90: 682-90. https://doi.org/10.1080/08035250119773

6. Baqui AH, Black RE, Arifeen SE, Hill K, Mitra SN, Sabir AA. Causes of childhood deaths in Bangladesh: results of a nationwide verbal autopsy study. Bulletin of the World Health Organization 1998; 76: 161- 71 .

7. Rashid SF, Hadi A, Afsana K, Begum SA. Acute respiratory infections in rural Bangladesh: cultural understandings, practices and the role of mothers and community health volunteers. Tropical Medicine and International Health 2001; 6: 249-55.

https://doi.org/10.1046/j.13653156.2001.0 0702.x

8. Schofield C, Ashworth A. Why have mortality rates for severe malnutrition remained so high? Bulletin of the World Health Organization 1996; 74: 223-9.

9. MOHFW, DGHS. Government of Bangladesh. CARI Project. A Manual for the Management of the Young Child with an Acute Respiratory Infection 1993; 3: 2123.

10. Pediatric Nutrition and Nutritional Deficiency States. In: Gupte S, (editor). The Short Textbook of Pediatrics. $10^{\text {th }}$ ed. New Delhi, JAYPEE Brothers, 2004; 71:116-154.

11. Victoria CG, Kirkwood BR, Ashworth A, Black RE, Rogers S, Sazawal S, et al. Potential intervention for the prevention of childhood pneumonia in developing countries: improving nutrition. American Journal of Clinical Nutrition 1999; 70: 309-20.

https://doi.org/10.1093/ajcn/70.3.309

PMid: 10479192

12. Talukder MQK, Das DK. Nutrition status and acute respiratory tract infection. Bangladesh Journal of Child Health 1987; 11: 149-53.

13. Tomkins A, Watson F. Malnutrition and Infection. Available from:

http://www.unsystem.org /scn/ archives/ npp05/ ch4.htm (Accessed on 22 March 2006).

14. UNICEF. Bangladesh- Health and Nutrition. Available from: http://www.unicef.orgfbangladeshlhealthnutrition-377html (Accessed on 11 October 2005).

15. Shakur MS, Banu N, Ehsan MA. Clinical, biochemical and socioeconomic factors associated with severe degree malnutrition in children admitted in Dhaka Shishu (Children) Hospital. Dhaka Shishu (Children) Hospital Journal 1991; 7: 5-12. https://doi.org/10.1093/ajcn/25.7.690 PMid: 4624650

16. James JW. Longitudinal study of morbidity of diarrhea and respiratory infections in malnourished children. American Journal of Clinical Nutrition 1972; 25: 690-4.

17. Tupasi TE, Mangubat NV, Sunico MES, Magdangal DM, Navarro EE, Lenoor ZA, et al. Malnutrition and acute respiratory tract infections in Fillipino children. Reviews of Infectious Disease1990; 12: 657-9.

https://doi.org/10.1093/clinids/12.Supplem ent_8.S1047

PMid: 2270404

18. Amin MR, Begum KA, Banu N, Ehsan MA, Akbar MS. Socio economic determinants and biochemical status of severely malnourished children. Dhaka Shishu (Children) Hospital Journal 1991; 7: 71-7.

19. Berkowitz FE. Infections in children with severe protein-energy malnutrition. Pediatric Infectious Disease -Journal 1992; 11: $750-9$. 
https://doi.org/10.1097/000064541992090 00-00015

PMid: 1448316

20. Antonio Pio. Standard case management of pneumonia in children in developing countries: the cornerstone of the acute respiratory infection programme. Bulletin of the World Health Organization 2003; 81: 9-11.

21. Bhawya Banga. Pneumonia in Children. Government of India. Available from: http//pib.nic.in/ feature /febr2000/ f300620002. html (Accessed on 22 March 2006).

22. Falade AG, Tschappeler H, Greenwood BM, Mulholland EK. Use of simple clinical signs to predict pneumonia in young Gambian children: the influence of malnutrition. Bulletin of the World Health Organization 1995; 73: 299-4.

23. Arora NS, Rochester DF. Effect of body weight and muscularity on human diaphragm muscle mass, thickness and area. Lancet 1982; 52: 64-70.

https://doi.org/10.1152/jappl.1982.52.1.64

PMid: 7061279
24. Kanchi P, Kakeri MK. A hospital based observational study of acute respiratory infection and some associated epidemiological factors in children of 05 years of age group. Bombay Hospital Journal. Available from: http:/ bhj. org / journal/ april 2005/ html/ original a hospital 126 .htm (Accessed on 22 March 2006).

25. Wafula EM, Ngamau DW, Onyango FE, Mirza NM, Njeru EK. X-ray diagnosable pneumonia in children with malnutrition at Kenyatta National Hospital. East African Medical Journal 1998; 75: 567-71.

26. Lin A, Santoro D. Protein Energy Malnutrition. Available from: http://www.emedicine.com/derm/topic 797.html (Accessed on 3 March 2003). 